\title{
Comparative Studies of Oak (Quercus petraea L.) Reservations within Cluj Forestry (Romania)
}

\author{
Adrian FÜSTÖS*, Liviu HOLONEC, Tabita-Teodora LISANDRU, Florin REBREAN \\ University of Agricultural Sciences and Veterinary Medicine Cluj-Napoca, Faculty of Horticulture, \\ Romania. \\ *)Corresponding author, e-mail: adrian.fustos89@gmail.com
}

BulletinUASVM Horticulture 74(1) / 2017

Print ISSN 1843-5254, Electronic ISSN 1843-5394

DOI:10.15835/buasvmcn-hort:12637

\begin{abstract}
In Romania it is necessary a sustained effort to extend the forest areas through artificial regeneration. This paper aimed to study the correlation between the heights and diameters of Quercus petraea trees obtained from seed reserves and their seed production. They were chosen 80 trees situated in four Quercus petraea seed reserves of Cluj county. The trees selected were located at a distance of 30 meters from each other. It has been found that the two measured variables (core diameter and trees height) were directly and positive correlated. The increase of the value of a variable leads to an increase in the other variable. Choosing trees with special qualities have a huge impact for transmitting genetic gain to new generations. Comprehensive analysis of stationary and vegetation characteristics resulted in reproductive material with significant values as seeds quality and adaptability.
\end{abstract}

Keywords: diameter, heights, genetically improved seeds, Quercus petraea, seed reserves

\section{Introduction}

Lately, there is a sharp decline in global forest areas (about 7 million ha annually). In Romania it is necessary a sustained effort to extend the forest areas through artificial regeneration. In this context, a special production process of the genetically improved seed bases has an important role (Milescu, 2002). In the Northern hemisphere are known more than 400 Quercus species which in the last decades were considered economically and ecologically important species being the subject of genetic, evolutionary and phylogeographic studies (Aldrich and Cavender-Bares 2011; Kremer et al., 2007; Gailing et al., 2013).

The aim of this study was to noted the correlation between the heights and diameters of the Quercus petraea trees from seed reserves and their seed production in Cluj county area.

\section{Materials and methods}

There were chosen 80 trees situated in four Quercus petraea seed reserves of Cluj County (Fig. 1), namely, two reserves located in Valea Fânațelor, across Sanpaul village: FIZ (forest inventory zone)
772A, 773B and the others two located in Feleac Valcele: FIZ 70 and 71C. The trees were selected after their taxonomic similarities, at the distance of 30 meters from each other. In order to characterize the studied trees, core diameter (Fig. 2) and total height measurements were made.

The correlation coefficient was calculated using the following equation:

$$
\mathrm{r}=\frac{\sum X Y-\frac{\sum X \sum Y}{N}}{\sqrt{\left(\sum x^{2}-\frac{\left(\sum X\right)^{2}}{N}\right)\left(\sum Y^{2}-\frac{\left(\sum Y\right)^{2}}{N}\right)}}
$$

Where: $\mathrm{x}$ - diameters of the trees;

$\mathrm{y}$ - heights of the trees;

$\mathrm{N}$ - number of trees.

\section{Results and discussion}

Data were obtained using Pearson correlation, and it has been found that the two measured variables (core diameter and trees height) were directly and positive correlated, in the sense that increasing the value of a variable leads to an increase in the other one (Tab. 1). The coefficient 


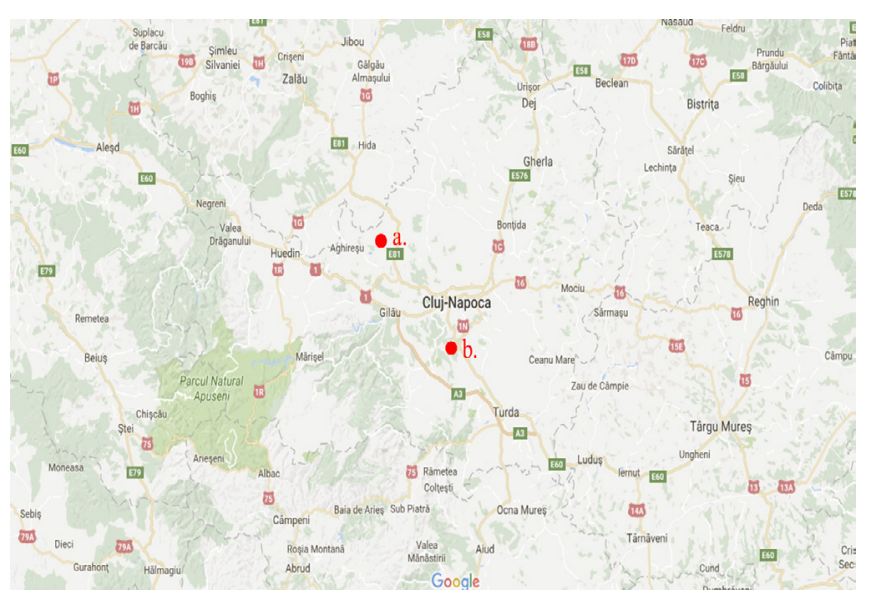

Fig.1. Localization of oak rezervations; a) Valea Fanatelor FIZ 772A, 773B; b) Feleac Valcele FIZ 70, 71C.

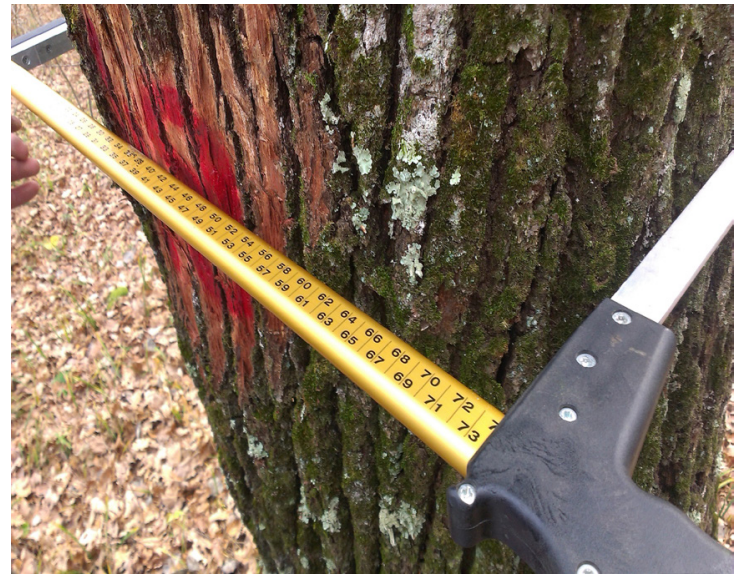

Fig.2. Measurement of tree diameter Photo by A. Fustos

Tab. 1. The coefficient of correlation between diameters and heights of studied oak species and the coefficaiant of variation

\begin{tabular}{cccc}
\hline \multirow{2}{*}{ Forest Area No. } & \multicolumn{2}{c}{ Coefficient of variation } & \multicolumn{2}{c}{$\begin{array}{c}\text { Coefficient of correlation } \\
(\mathrm{r})\end{array}$} \\
\cline { 2 - 4 } & Diameters & Heights & 0.77 \\
\hline $772 \mathrm{~A}$ & 0.21 & 0.065 & 0.18 \\
\hline $773 \mathrm{~B}$ & 0.27 & 0.084 & 0.19 \\
\hline 70 & 0.20 & 0.073 & 0.67 \\
\hline $71 \mathrm{C}$ & 0.25 & 0.069 & \\
\hline
\end{tabular}

of variation of the trees diameter was bigger than the trees height, which indicated that the measuring shafts were found in the upper limit register without major differences in their heights as diameters. In case of trees diametres, when the the coefficient of variability had a high value, the slope and the site conditions were directly influenced.

The results showed a significant differences between the studies and the amplitude variation is quite large in case of rezervation $71 \mathrm{C}$. The coefficient of variability indicated that, trees height was uniform within populations and it can be considered as being homogeneous (0.67).

\section{Conclusion}

In order to assure a genetic gain to the new generations ,choosing trees with special qualities have great importance. Comprehensive analysis of stationary and vegetation characteristics resulted in reproductive material with significant values as seeds quality and adaptability. Between core diameter and height of the studied oak species there was noted a directly and positive correlation, meaning that increasing the value of a variable lead to increased default to the other one.

\section{REFERENCES}

1. Aldrich P, Cavender-Bares J (2011). Quercus. In: Kole C (Ed). Wild croprelatives: genomic and breeding resources, forest trees. Springer.

2. Gailing $\mathrm{O}$, Bodénès $\mathrm{C}$, Finkeldey $\mathrm{R}$, Kremer $\mathrm{A}$, Plomion $\mathrm{C}$ (2013). Genetic mapping of EST derived simple sequence repeats (EST-SSRs) to identify QTL for leaf morphological characters in a Quercus robur full-sib family. Tree Genetics \& Genomes 9:1361-1367.

3. Kremer A, Casasoli M, Barreneche T, Bodénès C, Sisco P, Kubisiak T, Scalfi M, Leonardi E, Bakker E, Buiteveldt J, Romero-Severson J, Arumuganathan K, Derory J, ScottiSaintagne C, Roussel G, Bertocchi E, Lexer C, Porth I, Hebard F, Clark C, Carlson J, Plomion C, Koelewijn H-P, Villani F (2007) Fagaceae trees. In: Kole C (Ed). Genome mapping and molecular breeding in plants, volume 7. Forest trees. Springer.

4. Milescu I (2002). „Forest Economy”, Editura MUŞATINII, Suceava. 